\title{
Calcium induced skim-milk gelation during heating as affected by $\mathrm{pH}$
}

\author{
Glykeria Koutina $^{1} \cdot$ Mette Christensen $^{2}$. \\ Mette Bakman $^{2}$ - Ulf Andersen ${ }^{2}$ - Leif H. Skibsted ${ }^{1}$
}

Received: 13 January 2015 / Revised: 4 June 2015 / Accepted: 8 June 2015 /

Published online: 1 July 2015

C) INRA and Springer-Verlag France 2015

\begin{abstract}
Milk gels (acid or rennet) are used by dairy industry to produce dairy products such as yogurt and cheese. Enrichment of milk with calcium salts and heat treatment are known to produce "calcium-milk coagulum" as a new type of milk gels, due to reduction of milk protein charges through calcium binding. The combination of heat treatment and calcium addition to milk results in gel structures, but the effect of calcium addition and $\mathrm{pH}$ adjustment during heating of milk is still unclear. The role of added calcium and decreasing $\mathrm{pH}$ were investigated by addition of calcium chloride $(30 \mathrm{mM})$ to reconstituted skim milk followed by $\mathrm{pH}$ adjustment by hydrochloric acid and sodium hydroxide $(4.6<\mathrm{pH}<6.6$ investigated), followed by heating at $90{ }^{\circ} \mathrm{C}$ for $10 \mathrm{~min}$ and overnight storage at $22{ }^{\circ} \mathrm{C}$. In parallel, samples with no addition of calcium chloride were produced under the same conditions. The time and temperature to reach the gelation point, as detected by dynamic measurements of storage modulus $\left(\mathrm{G}^{\prime}\right)$, were decreasing as $\mathrm{pH}$ decreased without addition of calcium, while calcium addition made gelation time and temperature independent of $\mathrm{pH}$ except for $\mathrm{pH}$ 4.6. Heat treatment combined with calcium addition was found, using confocal laser microscopy, to provide a fine and dense gel structure for skim milk with higher $\mathrm{pH}$, while at $\mathrm{pH}$ lower than 5.6, the gel structure was similar to the structure of acid-induced gels. The last observation helps to establish a $\mathrm{pH}$ limit for production of calcium gels.
\end{abstract}

Keywords Calcium-milk coagulum $\cdot$ Milk gelation $\cdot$ Acid-calcium synergism $\cdot$ Mineral distribution

Leif H. Skibsted

1s@food.ku.dk

1 Department of Food Science, University of Copenhagen, Rolighedsvej 30, 1958 Frederiksberg C, Denmark

2 Arla Strategic Innovation Centre, Arla Foods Amba, 8220 Brabrand, Denmark 


\section{Introduction}

The delicate mineral equilibria between serum and micellar phase in milk are shifted during most of the processes used by the dairy industry such as cooling, acidification, addition of $\mathrm{NaCl}$ or other salts, and under heat treatment (Gaucheron 2005). The content and the interactions of calcium with proteins during milk processing are crucial for the final properties of dairy products, and a good understanding is important for future product development. The mineral fraction in milk is composed of calcium, magnesium, sodium, potassium, phosphorus, citrate, and chloride. Calcium and phosphorus play an important role in the milk system because they are part of the colloidal calcium phosphate (CCP) structure which is bound to certain regions of casein micelles and being important for their stability (Gaucheron 2005). Calcium in milk has received considerable attention due to the major contribution of calcium to the stabilization of the casein system during milk processing and during the formation of milk protein gels. During milk acidification, casein micelle integrity becomes affected and casein clusters are formed as building blocks of acid gels (Peng et al. 2009; Lucey 2002). In addition, CCP is solubilized from the casein micelles during acidification (Dalgleish and Law 1989) and calcium, liberated from the casein micelles, can participate in structure formation and influence the final structure and properties of protein gels in milk products. After CCP solubilization, there is a considerable amount of calcium attached to the carboxyl groups of glutamate and aspartate in the micelles which may participate in the structure of acid milk gels by forming bridges between two negative sizes of casein molecules (Dalgleish and Law 1989; van Hooydonk et al. 1986). During heat treatment of milk at elevated temperatures (higher than $40^{\circ} \mathrm{C}$ ), calcium and phosphorus are transferred from the serum phase to the micellar milk phase and form heat-induced CCP (Holt 1995). The heat-induced CCP connects with the existing CCP in the casein micelles and increases micelle size (Holt 1995). Holt (1995) showed that heat treatment at less than $95{ }^{\circ} \mathrm{C}$ for a few minutes will modify the mineral equilibria and that this modification will be reversible at cooling.

Calcium chloride may be added to milk during processing in order to modulate gel formation. Heat treatment of calcium-added milk is, however, challenging from a technological point of view due to the increase in micellar calcium with a concomitant decrease of $\mathrm{pH}$ inducing milk gelation (Ramasubramanian et al. 2008; Omoarukhe et al. 2010). At temperature between 4 and $40^{\circ} \mathrm{C}$, for conditions of constant $\mathrm{pH}$, the amount of calcium in serum milk phase is reduced with increasing temperature (Anema 2009b; Koutina et al. 2014), which may be explained by reduction in calcium phosphate solubility with increasing temperature, so-called a reversed solubility, which will lead to calcium phosphate precipitation (Singh 2004). One of the main changes of milk properties during heat treatment to temperatures higher than $65^{\circ} \mathrm{C}$ is the denaturation of whey proteins involving whey protein aggregation especially of $\beta$-lactoglobulin. $\beta$ Lactoglobulin creates complexes via sulfhydryl-disulfide interchange reactions with $\mathrm{k}$ casein or $\alpha$-lactalbumin or with other $\beta$-lactoglobulin molecules (Vasbinder and de Kruif 2003). Calcium contributes to $\beta$-lactoglobulin complex formation through formation of salt bridges with calcium bound to negative groups of $\beta$-lactoglobulin (Simons et al. 2002). According to Anema et al. (1993), the extent of K-casein dissociation from the casein micelles increases with an increase in total calcium content when milk is heated at $120{ }^{\circ} \mathrm{C}$ for $6 \mathrm{~min}(\mathrm{pH}$ between 6.3 and 7.4). 
Heat processing of calcium supplemented milk was found to lead to milk coagulation and to formation of a novel type of gel for which the term "calcium-milk coagulum" was coined (Ramasubramanian et al. 2012; Ramasubramanian et al. 2014). The addition of relatively high amounts of calcium salts will increase the ionic calcium concentration and decrease the $\mathrm{pH}$ which in combination with structural changes in whey proteins during heat treatment will lead to milk coagulation (Omoarukhe et al. 2010; Ramasubramanian et al. 2012; Vasbinder and de Kruif 2003). Still, the effect of $\mathrm{pH}$ on calcium gel formation under heat treatment is not well documented. The main objective of the present study is accordingly to describe the different structures formed by combinations of calcium addition and heat treatment to form calcium gels at $\mathrm{pH}$ typical for acidification of skim milk (6.6-4.6). Such a characterization will provide the understanding required by the dairy industry to develop the technology for producing novel dairy products.

\section{Materials and methods}

\subsection{Chemicals}

Calcium chloride dihydrate, sodium hydroxide solution, hydrochloric acid, and sodium azide of analytical grade were all from Sigma-Aldrich (St Louis, MO, USA). Fluorescein-5-isothiocyanate (FITC) was from Merck Millipore (Merck KGaA, Darmstadt, Germany). All aqueous solutions were made from deionized water (MilliQ plus, Millipore Corporation, Bedford, MA, USA).

\section{$2.2 \mathrm{pH}$ measurements}

$\mathrm{pH}$ values in all samples were measured at ambient temperature $\left(22^{\circ} \mathrm{C}\right)$ by a $\mathrm{pH}$ meter ( $\mathrm{pH}$ meter, 766-Calimatic, Knick Berlin-Zehlendorf, Germany) relative to international pH standards (Mettler, Toledo, Hasselager, Denmark).

\subsection{Reconstitution of skim milk powder}

Instant skimmed milk powder (milk protein $36 \%$, lactose $52 \%$, milk fat max. $1.25 \%$, minerals 8\%, and moisture 4\%; Arla Foods Ingredients, Viby J, Denmark) was reconstituted in deionized water at a level of $10 \%(w / w)$ and was stirred overnight at ambient temperature $\left(22{ }^{\circ} \mathrm{C}\right)$ to ensure complete hydration of casein micelles and equilibration of the mineral content. To avoid bacterial growth, sodium azide $(0.02 \%)$ was added to the reconstituted skim milk. The instant skim milk powder contained native soy lecithin at $0.04 \%$ level on powder. The product has whey protein nitrogen index (WPNI) between 1.5 and $6.0 \mathrm{mg}$ undenaturated whey protein nitrogen per gram of nonfat milk powder (medium heat process), and the percentage of native/denatured whey proteins is $50 / 50$. The instant skim milk powder was used because it has better dispersing and reconstitution characteristics than standard skim milk powder. According to Tran Le et al. (2007), native lecithin will not influence the heat-induced protein aggregation. The heat-induced interactions between whey proteins and casein 
micelles were highly influenced by hydrolysed and hydroxylated soybean lecithin (Tran Le et al. 2007).

\subsection{Milk enrichment with calcium at different pH}

The next day, the reconstituted skim milk was divided into smaller samples. Half of the samples was enriched with $30 \mathrm{mM}$ calcium using calcium chloride dihydrate $(\mathrm{ECa}=$ enriched with calcium chloride) under stirring for $10 \mathrm{~min}$, while the rest was not enriched ( $\mathrm{NCa}=$ Non-enriched with calcium chloride). The volume of each sample was $100 \mathrm{~mL}$. After $10 \mathrm{~min}$, the $\mathrm{pH}$ of all the samples (ECa and $\mathrm{NCa}$ ) was adjusted with $1.0 \mathrm{M} \mathrm{HCl}$ or $1.0 \mathrm{NaOH}$ to $6.6,6.0,5.6,5.2,5.0$, and 4.6. The dilution caused by the $\mathrm{HCl}$ or $\mathrm{NaOH}$ was kept constant for all samples by addition of deionized water when requested and then all samples were stirring for $10 \mathrm{~min}$ at ambient temperature. Skim milk samples with or without addition of $30 \mathrm{mM}$ calcium chloride dihydrate were heated and then cooled in a water bath using a three-step heating process: first step, 22 to $90{ }^{\circ} \mathrm{C}$ in $20 \mathrm{~min}$; second step, $90{ }^{\circ} \mathrm{C}$ for $10 \mathrm{~min}$; and third step, 90 to $22{ }^{\circ} \mathrm{C}$ in $20 \mathrm{~min}$. Consequently, all samples were left at $22{ }^{\circ} \mathrm{C}$ overnight before further analysis.

\subsection{Calcium and phosphorus analysis}

The separation between the micellar and the serum phase was done after centrifugation of all skim milk samples (Sorvall, RC 6 Plus Centrifuge, Axeb Lab Solutions, Albertslund, Denmark) at $10,000 \times g$ for $30 \mathrm{~min}$ at $22{ }^{\circ} \mathrm{C}$, using centrifuge tubes fitted with 10-kDa ultrafiltration membranes (Vinaspin 20, GE Healthcare, Bio-Science, AB, Uppsala, Sweden). Minerals that remained in the supernatant will be referred to as serum phase fraction components. The separation was done before the heating process at $90{ }^{\circ} \mathrm{C}$ for $10 \mathrm{~min}$ and after the heating process at $90{ }^{\circ} \mathrm{C}$ for $10 \mathrm{~min}$ and overnight storage at $22{ }^{\circ} \mathrm{C}$. Total calcium content was determined in the bulk milk preparation before being divided into samples with different $\mathrm{pH}$ levels. Serum contents of calcium were determined in all skim milk (NCa and $\mathrm{ECa}$ ) and in their serum phase fractions using an atomic absorption spectrometric method (IDF 2007). Micellar calcium was considered as the difference between total and serum calcium. Total phosphorus content was determined in the bulk milk preparation before being divided into samples with different $\mathrm{pH}$ levels. Serum contents of phosphorus were determined in all skim milk samples ( $\mathrm{NCa}$ and $\mathrm{ECa}$ ) in the serum phase fractions using a standard absorption spectrometric method (IDF 2006). Micellar phosphorus was considered as the difference between total and serum phosphorus.

\subsection{Rheological properties}

The rheological properties (storage modulus $\mathrm{G}^{\prime}$ ) of the skim milk ( $\mathrm{NCa}$ and ECa) as a function of time and temperature ramp were evaluated using a rheometer (Discovery Hybrid Rheometer HR-2, TA Instrument, Elstree, UK). The rheometer was equipped with concentric cylinder geometry (bob-cup; an outer radius of $14 \mathrm{~mm}$ and height of $42 \mathrm{~mm}$ ) with a temperature-controlled system. The cylinder 
was filled up with $10 \mathrm{~mL}$ from each sample. The heating process (temperature ramp) in the rheometer was first step, 22 to $90{ }^{\circ} \mathrm{C}$ in 20 min with a constant strain of $0.50 \%$ and frequency of $1 \mathrm{~Hz}$; second step, $90{ }^{\circ} \mathrm{C}$ for $10 \mathrm{~min}$ with a constant strain of $0.50 \%$ and frequency of $1 \mathrm{~Hz}$; and third step, 90 to $22{ }^{\circ} \mathrm{C}$ in 20 min with a constant strain of $0.50 \%$ and frequency of $1 \mathrm{~Hz}$. The rheological properties (storage modulus $\mathrm{G}^{\prime}$ ) of the final skim milk samples ( $\mathrm{NCa}$ and $\mathrm{ECa}$ ), after the heating process at $90{ }^{\circ} \mathrm{C}$ for $10 \mathrm{~min}$ and overnight storage at $22{ }^{\circ} \mathrm{C}$, as a function of frequency, were evaluated using a rheometer (Discovery Hybrid Rheometer HR-2, TA Instrument, Elstree, UK). The rheometer was equipped with concentric cylinder geometry (bob-cup; an outer radius of $14 \mathrm{~mm}$ and height of $42 \mathrm{~mm}$ ) with a temperature-controlled system. The cylinder was filled up with $10 \mathrm{~mL}$ from each sample. A frequency sweep test was performed at $22{ }^{\circ} \mathrm{C}$, and the frequency values were varied from 0.05 to $130 \mathrm{rad} / \mathrm{s}$ with a constant strain of $0.50 \%$. All measurements were within the linear viscoelastic region.

\subsection{Confocal laser scanning microscopy}

In order to observe the protein structure of the final skim milk samples ( $\mathrm{NCa}$ and ECa), after the heating process at $90{ }^{\circ} \mathrm{C}$ for $10 \mathrm{~min}$ and overnight storage at $22{ }^{\circ} \mathrm{C}$, the protein-specific fluorescein-5-isothiocyanate (FITC; dissolved in acetone) was used as a fluorescent probe. Approximately $1.0 \mathrm{~mL}$ of each sample was placed on a $24 \times 50$ coverslip (Gerhard Menzel GmbH, Braunschweig, Germany), mixed with FITC and then was immediately inverted for confocal laser scanning microscopy (CLSM) analysis. The microstructures of all samples were observed by an inverted confocal scanning laser microscopy (Leica DMIRE2, Leica Microsystems, Heidelberg, Germany). The samples were viewed using an oil immersion $\times 100$ lens having a pinhole diameter of 1 Airy unit. The emission filter was set at 500-650 nm for FITC which was excited at a wavelength $488 \mathrm{~nm}$. Micrographs of the samples visualize proteins in green color. The micrographs were taken in size $512 \times 512$ pixels, having an average of two frames. Image analysis of CLSM micrographs was performed using ImageJ software (Research Service Branch, National Institute of Health, Maryland, USA). At least three micrographs were obtained for each sample and were analyzed using the ImageJ software. Firstly, the color of the images was spilt into three channels (red, green, and blue) and for further analysis, the green color was chosen because the proteins were visualized as green areas by the microscopy. Secondly, the density of the green color was adjusted and each image was converted using the "black background" function. Finally, the specific function "analyze particles" gave a final percentage of the green color area used as percentage of protein gel for each sample.

\subsection{Statistical analysis}

One-way ANOVA from the SPSS statistical software (version SPSS 19.0, 2010, IBM Danmark ApS, Kgs. Lyngby, Denmark) was used for handling the data. Paired comparison between means for each parameter was carried out using Tukey's test, when a significant probability was distinguished $(P<0.05)$. 


\section{Results}

\subsection{Calcium and phosphorus equilibria}

After addition of calcium chloride, the samples were stirring for $10 \mathrm{~min}$ before the $\mathrm{pH}$ adjustment. In our preliminary experiments, samples stirred for $24 \mathrm{~h}$ showed comparable final structure as samples stirred for $10 \mathrm{~min}$ and for practical reasons, the 10-min trials were used. Table 1 shows the concentration of micellar and serum calcium and micellar and serum phosphorus in skim milk before heating (Table 1a) and after the heating

Table 1 Concentration of micellar and serum calcium $(\mathrm{mM})$ and micellar and serum phosphorus (mM) of skim milk samples at different $\mathrm{pH}$ at $22{ }^{\circ} \mathrm{C}$

\begin{tabular}{|c|c|c|c|c|c|}
\hline Sample & $\mathrm{pH}$ & Micellar Ca & Serum Ca & Micellar P & Serum P \\
\hline \multicolumn{6}{|l|}{$\mathrm{a}$} \\
\hline $\mathrm{NCa}$ & 6.6 & $17.8 \pm 0.8^{\mathrm{a}}$ & $8.8 \pm 0.8^{\mathrm{a}}$ & $18.9 \pm 0.8^{\mathrm{a}}$ & $9.3 \pm 0.8^{\mathrm{a}}$ \\
\hline $\mathrm{NCa}$ & 6.0 & $14.3 \pm 2.5^{\mathrm{b}}$ & $12.3 \pm 2.5^{\mathrm{b}}$ & $17.3 \pm 1.20^{\mathrm{a}}$ & $10.9 \pm 1.2^{\mathrm{a}}$ \\
\hline $\mathrm{NCa}$ & 5.6 & $11.6 \pm 0.8^{\mathrm{b}}$ & $15.0 \pm 0.8^{\mathrm{b}}$ & $13.3 \pm 0.3^{\mathrm{b}}$ & $14.9 \pm 0.3^{\mathrm{b}}$ \\
\hline $\mathrm{NCa}$ & 5.2 & $7.1 \pm 1.6^{\mathrm{c}}$ & $19.5 \pm 1.6^{\mathrm{c}}$ & $10.1 \pm 0.4^{\mathrm{c}}$ & $18.1 \pm 0.4^{\mathrm{c}}$ \\
\hline $\mathrm{NCa}$ & 5.0 & $6.8 \pm 0.6^{\mathrm{c}}$ & $19.8 \pm 0.6^{\mathrm{c}}$ & $8.8 \pm 0.5^{\mathrm{c}}$ & $19.3 \pm 0.5^{\mathrm{c}}$ \\
\hline $\mathrm{NCa}$ & 4.6 & $1.4 \pm 0.02^{\mathrm{d}}$ & $25.2 \pm 0.02^{\mathrm{d}}$ & $7.0 \pm 0.2^{\mathrm{d}}$ & $21.2 \pm 0.2^{\mathrm{d}}$ \\
\hline $\mathrm{ECa}$ & 6.6 & $32.2 \pm 4.0^{\mathrm{a}}$ & $24.5 \pm 4.0^{\mathrm{a}}$ & $15.1 \pm 0.7^{\mathrm{a}}$ & $12.7 \pm 0.7^{\mathrm{a}}$ \\
\hline $\mathrm{ECa}$ & 6.0 & $24.0 \pm 1.0^{\mathrm{a}}$ & $32.7 \pm 1.0^{\mathrm{a}}$ & $13.6 \pm 0.5^{\mathrm{a}}$ & $14.2 \pm 0.5^{\mathrm{a}}$ \\
\hline $\mathrm{ECa}$ & 5.6 & $19.8 \pm 3.0^{\mathrm{b}}$ & $36.9 \pm 3.0^{\mathrm{b}}$ & $12.6 \pm 0.7^{\mathrm{b}}$ & $15.1 \pm 0.7^{\mathrm{b}}$ \\
\hline $\mathrm{ECa}$ & 5.2 & $12.8 \pm 2.1^{\mathrm{b}}$ & $43.9 \pm 2.1^{\mathrm{b}}$ & $11.5 \pm 0.9^{b}$ & $16.2 \pm 0.9^{\mathrm{b}}$ \\
\hline $\mathrm{ECa}$ & 5.0 & $4.2 \pm 5.1^{\mathrm{c}}$ & $52.5 \pm 5.1^{\mathrm{c}}$ & $9.8 \pm 0.1^{\mathrm{c}}$ & $18.0 \pm 0.1^{\mathrm{c}}$ \\
\hline $\mathrm{ECa}$ & 4.6 & $2.8 \pm 0.01^{\mathrm{c}}$ & $53.9 \pm 0.01^{\mathrm{c}}$ & $2.1 \pm 0.01^{\mathrm{d}}$ & $25.7 \pm 0.01^{\mathrm{d}}$ \\
\hline \multicolumn{6}{|l|}{$\mathrm{b}$} \\
\hline $\mathrm{NCa}$ & 6.6 & $16.0 \pm 0.1^{\mathrm{a}}$ & $10.6 \pm 0.1^{\mathrm{a}}$ & $14.6 \pm 0.4^{\mathrm{a}}$ & $13.6 \pm 0.4^{\mathrm{a}}$ \\
\hline $\mathrm{NCa}$ & 6.0 & $13.6 \pm 0.9^{\mathrm{a}}$ & $13.0 \pm 0.9^{\mathrm{a}}$ & $12.5 \pm 0.3^{b}$ & $15.7 \pm 0.3^{\mathrm{b}}$ \\
\hline $\mathrm{NCa}$ & 5.6 & $10.0 \pm 0.4^{\mathrm{b}}$ & $16.6 \pm 0.4^{\mathrm{b}}$ & $10.5 \pm 0.5^{\mathrm{c}}$ & $17.7 \pm 0.5^{\mathrm{c}}$ \\
\hline $\mathrm{NCa}$ & 5.2 & $5.9 \pm 0.6^{\mathrm{c}}$ & $20.9 \pm 0.6^{\mathrm{c}}$ & $8.7 \pm 0.1^{\mathrm{d}}$ & $19.5 \pm 0.1^{\mathrm{d}}$ \\
\hline $\mathrm{NCa}$ & 5.0 & $4.0 \pm 0.6^{\mathrm{c}}$ & $22.6 \pm 0.6^{\mathrm{c}}$ & $7.7 \pm 0.2^{\mathrm{d}}$ & $20.5 \pm 0.2^{\mathrm{d}}$ \\
\hline $\mathrm{NCa}$ & 4.6 & $1.3 \pm 1.1^{\mathrm{d}}$ & $25.3 \pm 1.1^{\mathrm{d}}$ & $7.5 \pm 0.2^{\mathrm{d}}$ & $20.7 \pm 0.2^{\mathrm{d}}$ \\
\hline $\mathrm{ECa}$ & 6.6 & $28.5 \pm 0.6^{\mathrm{a}}$ & $28.2 \pm 0.6^{\mathrm{a}}$ & $22.4 \pm 1.2^{\mathrm{a}}$ & $5.4 \pm 1.2^{\mathrm{a}}$ \\
\hline $\mathrm{ECa}$ & 6.0 & $20.5 \pm 1.6^{\mathrm{b}}$ & $36.1 \pm 1.6^{\mathrm{b}}$ & $18.8 \pm 0.7^{\mathrm{b}}$ & $9.0 \pm 0.7^{\mathrm{b}}$ \\
\hline $\mathrm{ECa}$ & 5.6 & $13.6 \pm 0.5^{\mathrm{c}}$ & $43.0 \pm 0.5^{\mathrm{c}}$ & $16.0 \pm 0.6^{\mathrm{b}}$ & $11.7 \pm 0.6^{\mathrm{b}}$ \\
\hline $\mathrm{ECa}$ & 5.2 & $9.4 \pm 1.2^{\mathrm{d}}$ & $47.3 \pm 1.2^{\mathrm{d}}$ & $11.8 \pm 0.7^{\mathrm{c}}$ & $16.0 \pm 0.7^{\mathrm{c}}$ \\
\hline $\mathrm{ECa}$ & 5.0 & $6.5 \pm 0.2^{\mathrm{d}}$ & $50.2 \pm 0.2^{\mathrm{d}}$ & $8.9 \pm 0.5^{\mathrm{c}}$ & $18.8 \pm 0.5^{\mathrm{c}}$ \\
\hline $\mathrm{ECa}$ & 4.6 & $5.0 \pm 0.5^{\mathrm{f}}$ & $51.7 \pm 0.5^{\mathrm{f}}$ & $5.9 \pm 1.2^{\mathrm{d}}$ & $21.9 \pm 1.2^{\mathrm{d}}$ \\
\hline
\end{tabular}

(a) Before heating process and (b) after the heating process at $90{ }^{\circ} \mathrm{C}$ for $10 \mathrm{~min}$ and overnight storage at $22^{\circ} \mathrm{C}$. Means \pm standard deviation with different letters for each parameter at different $\mathrm{pH}$ differ significantly $(P<0.05)$. Total calcium $(\mathrm{mM}) \mathrm{NCa} 26.6 \pm 0.3$ and ECa $56.7 \pm 2.6$. Total phosphorus $(\mathrm{mM}) \mathrm{NCa} 28.2 \pm 1.0$ and ECa $27.8 \pm 0.1$

$N C a$ non-enriched with calcium chloride, $E C a$ enriched with calcium chloride 
process at $90{ }^{\circ} \mathrm{C}$ for 10 min and overnight storage at $22{ }^{\circ} \mathrm{C}$ (Table $1 \mathrm{~b}$ ), as mean $\pm \mathrm{SD}$ of two independent replicates. During milk acidification, the calcium and phosphorus equilibria between the micellar and the serum phase are disturbed and due to solubilization of colloidal calcium phosphate (CCP), more calcium and phosphorus are transferred from the micelles into the serum milk phase (van Hooydonk et al. 1986; Dalgleish and Law 1988). The increase in concentrations of serum calcium and phosphorus (Table 1), resulting from the $\mathrm{pH}$ decrease of skim milk ( $\mathrm{NCa}$ and $\mathrm{ECa}$ ) from 6.6 to 4.6, occurred with a concomitant decrease in the concentration of micellar calcium and phosphorus (Table 1). For decreasing $\mathrm{pH}$, the addition of calcium chloride $(30 \mathrm{mM})$ to enriched skim milk (ECa) skim milk (Table 1) caused an increase in both micellar and serum calcium which were more pronounced for the serum milk fraction at $\mathrm{pH}$ lower than 5.6. For skim milk samples enriched with calcium chloride (ECa) before heating (Table 1a), slightly more phosphorus was observed in the serum phase than for non-enriched ( $\mathrm{NCa}$ ) skim milk. For skim milk samples enriched with calcium chloride (ECa) after the heating process at $90{ }^{\circ} \mathrm{C}$ for $10 \mathrm{~min}$ and overnight storage at $22{ }^{\circ} \mathrm{C}$ (Table 1b), less phosphorus was observed in the serum phase than for non-enriched calcium chloride $(\mathrm{NCa})$ skim milk.

\subsection{Dynamic rheology of calcium induced gels}

An example of the storage modulus $\left(\mathrm{G}^{\prime}\right)$ evolution as a function of time and temperature ramp for a representative skim milk sample (ECa; $\mathrm{pH}$ 6.6) can be seen in Fig. 1. Table 2 shows the time period ( $\mathrm{min})$ and temperature $\left({ }^{\circ} \mathrm{C}\right)$ of the gelation point of skim milk at different $\mathrm{pH}(\mathrm{NCa}$ and $\mathrm{ECa})$. As can be seen from Fig. 1, in the beginning of the dynamic measurements, $\mathrm{G}^{\prime}$ as a function of time, the system is still liquid as evidenced by a lag phase (straight line box). However, when the first aggregates start to be formed, a sudden increase (gelation point) can be observed (Fig. 1; dash line box) which growths more as a firmer gel is being produced until reaching a plateau (Fig. 1; dot line box) (Ercili Cura et al. 2009). In conclusion, all samples (NCa and ECa) reached the gelation point during the first step of the heating process, as can be seen in Table 2 (first step, 22 to $90{ }^{\circ} \mathrm{C}$ in $20 \mathrm{~min}$ ). For non-enriched (NCa) samples, the temperature and the time to reach the gelation point were decreasing as $\mathrm{pH}$ was decreased (Table 2), while for skim milk samples enriched with calcium chloride (ECa), the time and the temperature of the

Fig. 1 Storage modulus $\left(\mathrm{G}^{\prime}\right)$ as a function of time and temperature ramp of a representative skim milk sample (ECa pH 6.6). The three different boxes refer to the three different regions during the formation of a milk gel: box with straight line, initial lag phase; box with dash line, rapid increase phase; and box with dot line, plateau phase

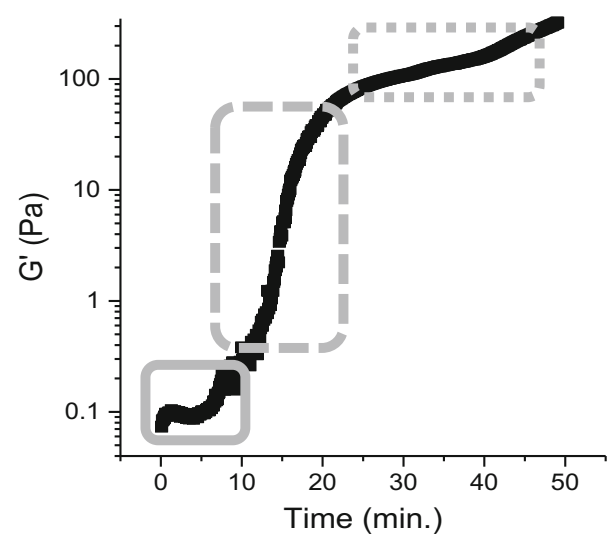


Table 2 The time period (in minutes from the initiation of the first step) and temperature $\left({ }^{\circ} \mathrm{C}\right)$ of the gelation point of the skim milk samples at different $\mathrm{pH}$

\begin{tabular}{llll}
\hline Sample & $\mathrm{pH}$ & Time (minutes) & Temperature $\left({ }^{\circ} \mathrm{C}\right)$ \\
\hline $\mathrm{NCa}$ & 6.6 & No gel formation & No gel formation \\
$\mathrm{NCa}$ & 6.0 & No gel formation & No gel formation \\
$\mathrm{NCa}$ & 5.6 & $17.0 \pm 0.1^{\mathrm{a}}$ & $81.0 \pm 0.1^{\mathrm{a}}$ \\
$\mathrm{NCa}$ & 5.2 & $10.0 \pm 0.1^{\mathrm{b}}$ & $55.0 \pm 0.1^{\mathrm{b}}$ \\
$\mathrm{NCa}$ & 5.0 & $7.8 \pm 0.4^{\mathrm{c}}$ & $49.5 \pm 0.7^{\mathrm{c}}$ \\
$\mathrm{NCa}$ & Gelation prior to heating & Gelation prior to heating \\
$\mathrm{ECa}$ & 4.6 & $13.0 \pm 0.1^{\mathrm{a}}$ & $70.0 \pm 0.1^{\mathrm{a}}$ \\
$\mathrm{ECa}$ & 6.6 & $12.8 \pm 0.5^{\mathrm{a}}$ & $67.0 \pm 1.8^{\mathrm{a}}$ \\
$\mathrm{ECa}$ & 6.0 & $12.7 \pm 0.4^{\mathrm{a}}$ & $67.0 \pm 1.3^{\mathrm{a}}$ \\
$\mathrm{ECa}$ & 5.6 & $12.2 \pm 0.4^{\mathrm{a}}$ & $65.0 \pm 1.2^{\mathrm{a}}$ \\
$\mathrm{ECa}$ & 5.2 & $11.7 \pm 1.1^{\mathrm{a}}$ & $63.0 \pm 3.7^{\mathrm{a}}$ \\
$\mathrm{ECa}$ & 5.0 & $5.5 \pm 0.1^{\mathrm{b}}$ & $42.0 \pm 0.1^{\mathrm{b}}$ \\
\hline
\end{tabular}

The heating process in the rheometer was first step, 22 to $90^{\circ} \mathrm{C}$ in $20 \mathrm{~min}$; second step, $90{ }^{\circ} \mathrm{C}$ for $10 \mathrm{~min}$; and third step, 90 to $22{ }^{\circ} \mathrm{C}$ in $20 \mathrm{~min}$. Means \pm standard deviation with different letters for each parameter at different $\mathrm{pH}$ differ significantly $(P<0.05)$

$\mathrm{NCa}$ non-enriched with calcium chloride, $E C a$ enriched with calcium chloride

gelation point were between 13 and $12 \mathrm{~min}$ and 70 and $60{ }^{\circ} \mathrm{C}$ for $\mathrm{pH}$ values between 6.6 and 5.0 and $5.5 \mathrm{~min}$ and $42{ }^{\circ} \mathrm{C}$ for $\mathrm{pH}$ 4.6.

\subsection{Rheology and microscopy of calcium-induced gels}

Figure 2 shows $\mathrm{G}^{\prime}$ as a function of frequency (rheology properties) as the mean $\pm \mathrm{SD}$ of two independent replicates, and Fig. 3 shows representative microscopy images of skim milk gels at different $\mathrm{pH}$ at $22{ }^{\circ} \mathrm{C}(\mathrm{NCa}$ and $\mathrm{ECa})$.

Non-enriched calcium chloride ( $\mathrm{NCa}$ ) samples having $\mathrm{pH} 6.6$ and 6.0 were not able to form a gel because at this high $\mathrm{pH}$, casein micelles have high negative charge and repulsion forces prohibit formation of gel networks (Zoon et al. 1989). As $\mathrm{pH}$ is reduced from 6.0 to 5.4, dissociation of the CCP occurs and caseins will start to form loosely entangled aggregates (Fig. 3). The microscopy images (Fig. 3a) of non-enriched calcium chloride ( $\mathrm{NCa}$ ) samples show a network that becomes denser as the $\mathrm{pH}$ is decreased, which was confirmed by image analysis showing that approximately $20 \%$ of partial area at $\mathrm{pH} 6.6$ increased to $29 \%$ partial area at $\mathrm{pH} 4.6$. These samples all had macroscopic properties as gels.

Skim milk samples enriched with calcium chloride (ECa) is from Fig. 3 seen to form a gel network at all $\mathrm{pH}$ values investigated, and from the rheological data, it is further concluded that the gels become stronger with decreasing $\mathrm{pH}$ (Fig. 2). In addition, the rheological data (Fig. 2) shows that enriched with calcium chloride samples (ECa) gave stronger gels (higher $\mathrm{G}^{\prime}$ values) than nonenriched calcium chloride $(\mathrm{NCa})$ samples from $\mathrm{pH} 6.6$ to 5.2. In contrast, at $\mathrm{pH}$ 5.0, the non-enriched calcium chloride $(\mathrm{NCa})$ samples had higher $\mathrm{G}^{\prime}$ values than enriched with calcium chloride samples $(\mathrm{ECa})$, while at $\mathrm{pH} 4.6$, the $\mathrm{G}^{\prime}$ 
Fig. 2 Storage modulus $\left(\mathrm{G}^{\prime}\right)$ as a function of frequency of skim milk at different $\mathrm{pH}$ at $22{ }^{\circ} \mathrm{C}$. a $\mathrm{NCa}=$ non-enriched with calcium chloride. $\mathbf{b} \mathrm{ECa}=$ enriched with calcium chloride. The symbols in the two diagrams referring to the following $\mathrm{pH}$ values: $\mathrm{pH} 6.5$ (black square), 6.0 (white circle), 5.6 (black triangle), 5.2 (white square), 5.0 (black diamond), and 4.6 (triangle pointing to the right). For the $\mathrm{NCa}=$ non-enriched with calcium chloride (a), the samples with pH 6.5 and 6.0 are not included in the figure

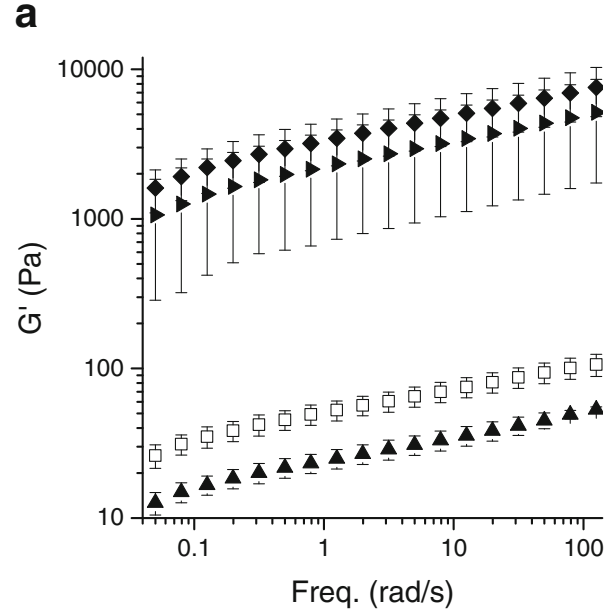

b

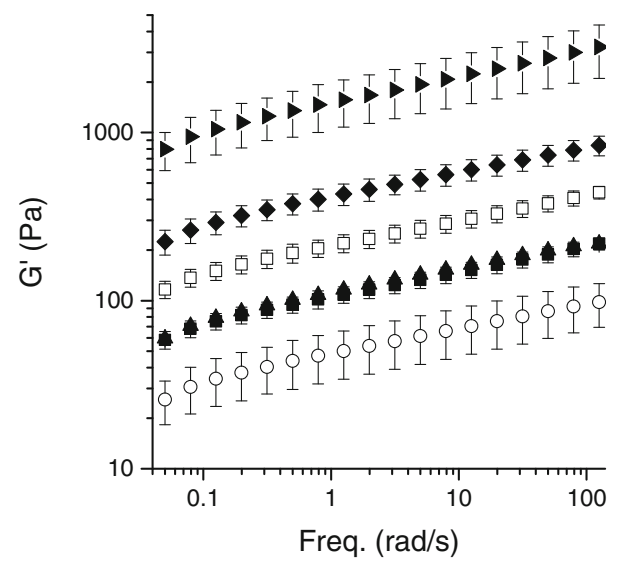

values of non-enriched calcium chloride $(\mathrm{NCa})$ and enriched with calcium chloride (ECa) samples were almost the same. The microscopy images (Fig. 3b) of enriched with calcium chloride (ECa) samples show a network that becomes less dense as $\mathrm{pH}$ is decreasing, and image analysis confirmed this tendency with partial areas of $42 \%$ at $\mathrm{pH} 6.6$ and $28 \%$ at $\mathrm{pH} 4.6$. These samples all had macroscopic properties as gels.

\section{Discussion}

\subsection{Calcium and phosphorus distribution in calcium gels at different $\mathrm{pH}$}

As is clearly seen from Table 1, both the calcium and phosphorus distribution between the micellar and serum phase are highly affected by acidification of milk, confirming the results of previous studies (Anema 2009a; Anema 2009b; Dalgleish and Law 1989; 
a

$(\mathrm{C} \text { pH: 5.6; } 20 \% \pm 3)^{\mathrm{x}}$

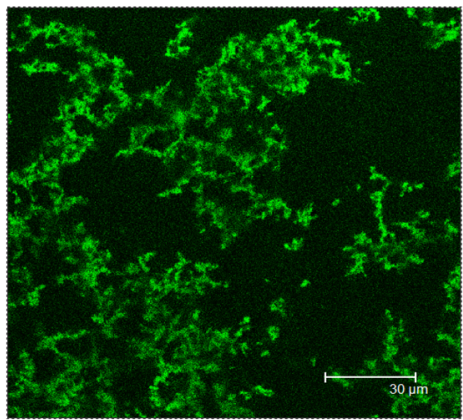

(D pH: 5.2; $22 \% \pm 3)^{\mathrm{x}}$

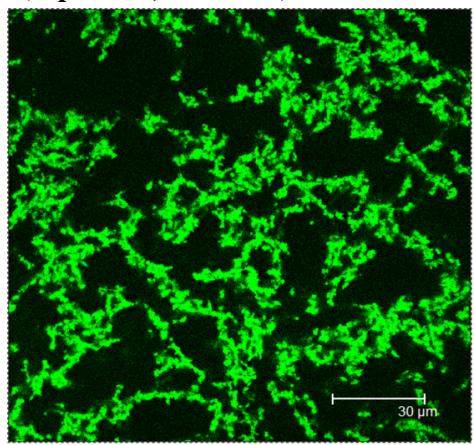

$(\mathbf{E} \text { pH: } 5.0 ; 30 \% \pm 3)^{\mathrm{y}}$

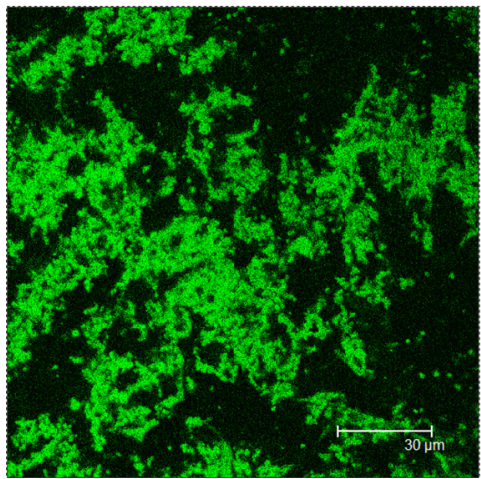

Fig. 3 CLSM micrographs showing the microstructure of skim milk samples at different $\mathrm{pH}(A, \mathrm{pH} 6.6 ; B$, $\mathrm{pH} 6.0 ; C, \mathrm{pH} 5.6 ; D, \mathrm{pH} 5.2 ; E, \mathrm{pH} 5.0 ; F, \mathrm{pH} 4.6)$ at $22{ }^{\circ} \mathrm{C} ; \mathbf{a ~ N C a}=$ non-enriched with calcium chloride; $\mathbf{b}$ $\mathrm{ECa}=$ enriched with calcium chloride. The FITC-stained protein appears green in all micrographs. Information inside the parenthesis indicate the $\mathrm{pH}$ of each sample encode with letters, and the particle area from image analysis using ImageJ software, as mean from three independent samples (\%) \pm standard deviation. Means with different letters differ significantly $(P<0.05)$. For the $\mathrm{NCa}=$ non-enriched with calcium chloride $(\mathbf{a})$, the samples with $\mathrm{pH} 6.5$ and 6.0 are not included in the figure

Koutina et al. 2014; Mekmene et al. 2010; van Hooydonk et al. 1986; Visser et al. 1986). In addition, enrichment of milk with calcium chloride is seen to increase both 


\section{b}

(A pH: 6.6; $42 \% \pm 2)^{\mathrm{a}}$

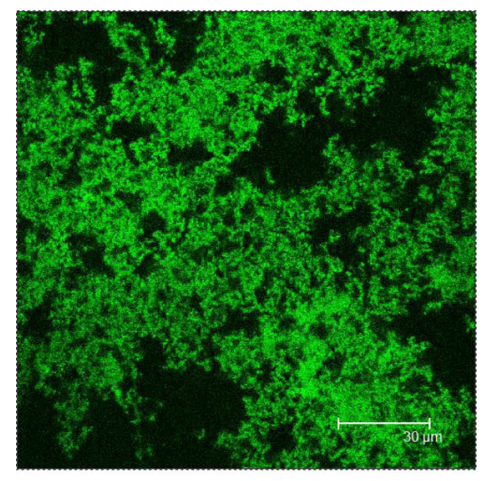

(B pH: 6.0; $35 \% \pm 3)^{\text {a,b }}$

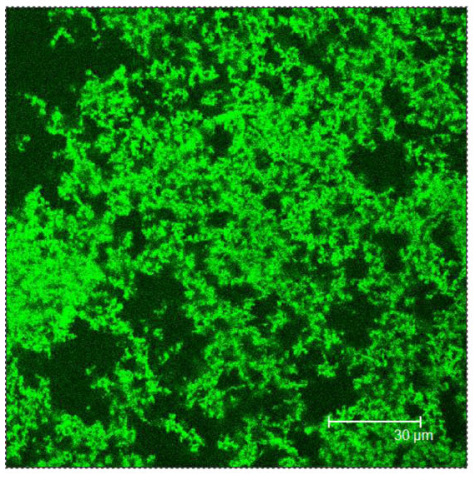

$(\mathrm{C} \text { pH: } 5.6 ; 35 \% \pm 3)^{\mathrm{b}}$

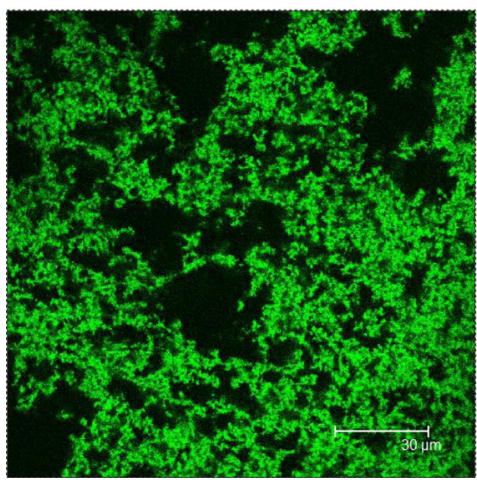

Fig. 3 (continued)
(D pH: 5.2; $30 \% \pm 1)^{\mathrm{b}, \mathrm{c}}$

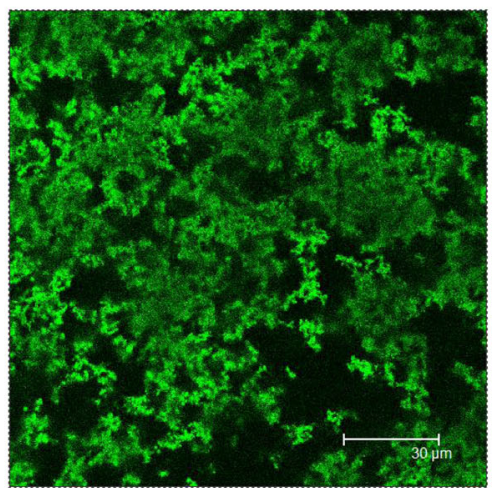

$(\mathrm{E} \text { pH: 5.0; 26 } \pm 3)^{\mathrm{c}}$

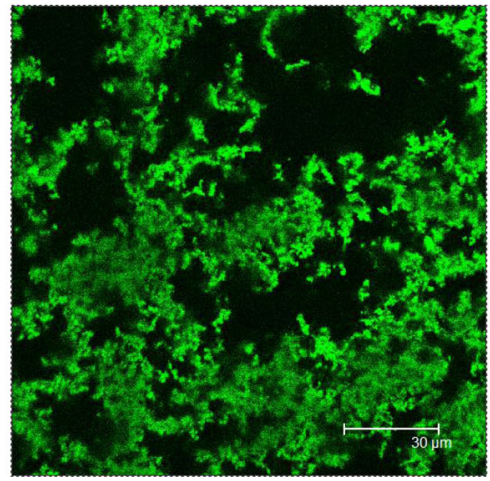

(F pH: 4.6; $28 \pm 6)^{\mathrm{c}}$

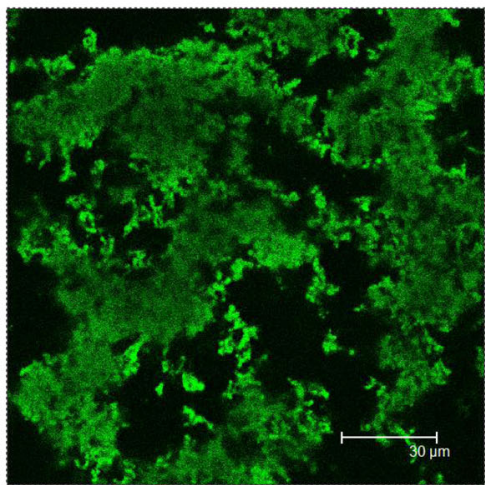

micellar and serum calcium, but for $\mathrm{pH}$ lower than 5.6, the majority of added calcium remained in the serum phase.

As is further seen from Table 1a, the addition of calcium chloride to skim milk (ECa) causes a slight increase of phosphorus in the serum phase, while as seen from Table $1 \mathrm{~b}$, the addition of calcium chloride (ECa) cause a decrease of 
phosphorus in the serum phase, after heating (Famelart et al. 1999; Koutina et al. 2015; Udabage et al. 2000). The decreasing concentration of phosphorus in the serum phase after addition of calcium chloride and heating (Table 1b) can be understood from the low solubility of calcium phosphate in the serum phase upon heating and the tendency to form supersaturated solutions (Mekmene et al. 2010). The decreased amount of phosphorus in the serum phase following calcium addition and heating seems to indicate that the added calcium binds serum phosphorus and that calcium and phosphorus together enter the micellar phase causing casein micelles to aggregate. The difference in mineral distribution between skim milk (ECa) before heating (Table 1a) and after the heating process at $90{ }^{\circ} \mathrm{C}$ for $10 \mathrm{~min}$ and overnight storage at $22{ }^{\circ} \mathrm{C}$ (Table $1 \mathrm{~b}$ ) can be explained by the shorter time for equilibration in the non-heated skim milk (less than $30 \mathrm{~min}$ ) compared to heated samples (overnight storage). The decreasing solubility of calcium phosphate at increasing temperature further contributes to this effect.

\subsection{Rheology and microscopy of calcium gels at different $\mathrm{pH}$}

For non-enriched calcium chloride (NCa) samples, the temperature and the time to reach the gelation point were found to decrease as $\mathrm{pH}$ decreased (Table 2). The combination of heating with acidification results in formation of aggregates leading to formation of a final gel network. Heat is known to denaturate whey proteins and further to result in binding of whey proteins to $\mathrm{K}$-casein on the surface of casein micelles (Vasbinder and de Kruif 2003). These binding interactions will not interrupt the removal of CCP from the casein micelles during acidification, but the dissociation of caseins from the micelles will be reduced especially at temperature around $20{ }^{\circ} \mathrm{C}$, as was used in this study (Singh et al. 1996; Law 1996; Dalgleish and Law 1988).

For enriched with calcium chloride (ECa) samples, the time and the temperature of the gelation point was around $13-12 \mathrm{~min}$ and $70-60^{\circ} \mathrm{C}$ for $\mathrm{pH}$ values between 6.6 and 5.0 and $5.5 \mathrm{~min}$ and $42^{\circ} \mathrm{C}$ for $\mathrm{pH} 4.6$. Addition of calcium chloride is known to make whey proteins more sensitive to denaturation and aggregation (Pappas and Rothwell 1991), and for all skim milk samples enriched with calcium chloride $(\mathrm{ECa})$, the gelation point was reached at temperatures between 60 and $70{ }^{\circ} \mathrm{C}$, in which temperature range the whey proteins are known to denaturate (de Wit and Klarenbeek 1984). At pH 4.6, the gelation point was reached faster and at lower temperature compared to higher $\mathrm{pH}$ probably because the high affinity for casein to casein bonds results in casein gelation as this low $\mathrm{pH}$ corresponding to the isoelectric point of caseins (Lucey and Lee 2004; Walstra and Jenness 1984). The pH decrease will increase the solubilization of CCP and calcium and phosphorus will dissolve from the casein micelles causing partial rearrangement of the inner structure of casein micelles to form a final acid gel network (Lucey 2002).

For skim milk samples not enriched with calcium chloride (NCa), the changes in microstructure were reflected in an increase in $\mathrm{G}^{\prime}$ value for the final milk gels (Figs. 2 and 3). At pH between 5.3 and 4.9 loosely entangled aggregates of proteins form more compact particles, while at $\mathrm{pH}$ lower than 4.8 , caseins aggregated rapidly into a gel network consisting of chains of compact spherical particles (Famelart et al. 2004). In addition, acid gels form a particular heterogeneous structure consisting of fairly large clusters with holes as seen also in Fig. 3a F (Roefs et al. 1990). These observations are 
confirmed by microscopy in the present study as seen from the microscopy images and further reflected in the rheological profile of the skim milk samples not enriched with calcium chloride $(\mathrm{NCa})$.

For the skim milk samples enriched with calcium chloride (ECa; Figs. 2 and 3), the addition of calcium chloride in combination with heat treatment causes the formation of a gel network independent of $\mathrm{pH}$ (Ramasubramanian et al. 2013; Ramasubramanian et al. 2014). Heating of milk causes denaturation of whey proteins and attachment to the surface of the casein micelles through the K-casein (Vasbinder and de Kruif 2003). Consequently, denatured whey proteins become sensitive to aggregation as the net charge of the proteins is decreased leading to less repulsion. The denatured whey proteins form linkages to whey proteins already bound to casein micelles which increasing the number and the strength of protein bonds in particles leading to a final gel network (Lucey et al. 1997). In addition, heated whey proteins are sensitive to aggregation in the presence of calcium ions causing the formation of a firm gel network as was confirmed by the higher $\mathrm{G}^{\prime}$ values (Fig. 2) of skim milk samples enriched with calcium chloride (ECa) compared to non-enriched calcium chloride (NCa) samples in the present study (Hongsprabhas and Barbut 1996; Simons et al. 2002).

At high $\mathrm{pH}$ (6.6-5.6), a fine gel structure was observed with negligible whey separation for enriched with calcium chloride (ECa) samples. Moreover, for enriched with calcium chloride (ECa) samples, the majority of added calcium remained in the serum milk phase at $\mathrm{pH} 5.2-4.6$, while at $\mathrm{pH}$ higher than 5.2, the added calcium was distributed more uniformly between the micellar and serum phases (Table 1). Addition of calcium in milk will accordingly cause an increase in the level of CCP available as a micellar-connecting agent forming calcium bridges between caseins. At $\mathrm{pH}$ around and below 5.2, CCP become completely solubilized and the majority of added calcium remains in the serum phase causing fewer rearrangements for the formation of a gel network. Consequently, at $\mathrm{pH}$ lower than 5.6, the effect of $\mathrm{pH}$ is dominating in relation to calcium addition for gel formation during milk heating.

\section{Conclusion}

A fine gel network has been demonstrated to be formed by addition of $30 \mathrm{mM}$ calcium chloride to skim milk followed by $\mathrm{pH}$ adjustment to values between 6.6 and 4.6 and heat treatment at $90{ }^{\circ} \mathrm{C}$ for 10 min before storage at $22^{\circ} \mathrm{C}$ overnight. In contrast for $\mathrm{pH}$ lower than 5.6, the effect of $\mathrm{pH}$ dominates over the effect of calcium chloride addition on protein gel formation. The formation of a gel network with little whey separation at relative high $\mathrm{pH}$ (6.6 to 5.6) was obtained by the combination of calcium addition and heat treatment. Such types of gel should be further investigated for production of new yogurt-like dairy products with high $\mathrm{pH}$.

\section{Acknowledgments This work was supported by Arla Foods Amba.}

\section{References}

Anema SG (2009a) Effect of milk solids concentration on the $\mathrm{pH}$, soluble calcium and soluble phosphate levels of milk during heating. Dairy Sci Technol 89:501-510 
Anema SG (2009b) Role of colloidal calcium phosphate in the acid gelation properties of heated skim milk. Food Chem 114:161-167

Anema SG, Singh H, Creamer LK (1993) The relative importance of protein and mineral concentrations on the dissociations of $\mathrm{K}$-casein from the micelles in heated reconstituted skim milk. IDF Document 9303: $227-235$

Dalgleish DG, Law AJR (1988) pH-induced dissociation of bovine casein micelles. 1. Analysis of liberated caseins. J Dairy Res 55:529-538

Dalgleish DG, Law AJR (1989) pH-induced dissociation of bovine casein micelles. 2. Mineral solubilization and its relation to casein release. J Dairy Res 56:727-735

de Wit JN, Klarenbeek G (1984) Effects of various heat treatments on structure and stability of whey proteins. J Dairy Sci 67:2701-2710

Ercili Cura D, Lantto R, Lille M, Andberg M, Kruus K, Buchert J (2009) Laccase-aided protein modification: effects on the structural properties of acidified sodium caseinate gels. Int Dairy J 19:737-745

Famelart MH, Le Graet Y, Raulot K (1999) Casein micelle dispersions into water, $\mathrm{NaCl}$ and $\mathrm{CaCl}_{2}$ : physicochemical characteristics of micelles and rennet coagulation. Int Dairy J 9:293-297

Famelart MH, Tomazewski J, Piot M, Pezennec S (2004) Comprehensive study of acid gelation of heated milk with model protein systems. Int Dairy J 14:313-321

Gaucheron F (2005) The minerals of milk. Reprod Nutr Dev 45:473-483

Holt C (1995) Effect of heating and cooling on the milk salts and their interaction with casein. In: International dairy federation special issue 9501. Heat-induced changes in milk, 2nd edn. International Dairy Federation, Brussels, pp 105-133

Hongsprabhas P, Barbut S (1996) $\mathrm{Ca}^{2+}$-induced gelation of whey protein isolate: effects of pre-heating. Food Res Int 29:135-139

IDF (2006) Milk. Determination of total phosphorus content. Method using molecular absorption spectroscopy. IDF Standard 42, Brussels, Belgium: Int Dairy Federation

IDF (2007) Milk and milk products. Determination of calcium, sodium, potassium and magnesium contents. Atomic absorption spectrometric method. IDF Standard 119, Brussels, Belgium: Int Dairy Federation

Koutina G, Knudsen JC, Andersen U, Skibsted LH (2014) Temperature effect on calcium and phosphorus equilibria in relation to gel formation during acidification of skim milk. Int Dairy J 36:65-73

Koutina G, Knudsen JC, Skibsted LH (2015) The effect of pH on calcium and phosphorus distribution between micellar and serum phase after enrichment of skim milk with calcium D-lactobionate. Dairy Sci Technol 95:63-74

Law AJR (1996) Effects of heat treatment and acidification on the dissociation of bovine casein micelles. J Dairy Res 63:35-48

Lucey JA (2002) Formation and physical properties of milk proteins gel. J Dairy Sci 85:281-294

Lucey JA, Lee WJ (2004) Structure and physical properties of yogurt gels: effect of inoculation rate and incubation temperature. J Dairy Sci 87:3153-3164

Lucey JA, Teo CT, Munro PA, Singh H (1997) Rheological properties at small (dynamic) and large (yield) deformations of acid gels made from heated milk. J Dairy Res 64:591-600

Mekmene O, Le Graet Y, Gaucheron F (2010) Theoretical model for calculating ionic equilibria in milk as a function of $\mathrm{pH}$ : comparison to experiment. J Agric Food Chem 58:4440-4447

Omoarukhe ED, On-Nom N, Grandison AS, Lewis MJ (2010) Effects of different calcium salts on properties of milk related to heat stability. Int J Dairy Technol 63:504-511

Pappas C, Rothwell J (1991) The effects of heating, alone or in the presence of calcium or lactose on calcium binding to milk proteins. Food Chem 42:183-201

Peng Y, Serra M, Horne DS, Lucey JA (2009) Effect of fortification with various types of milk proteins on the rheological properties and permeability of nonfat set yogurt. J Food Sci 74:C666-C673

Ramasubramanian L, Resticcia C, Deeth H (2008) Effect of calcium on the physical properties of stirred probiotic yogurt. J Dairy Sci 91:4164-4175

Ramasubramanian L, D'Arcy BR, Deeth HC (2012) Heat-induced coagulation of whole milk by high levels of calcium chloride. Int J Dairy Technol 65:183-190

Ramasubramanian L, Webb R, D'Arcy BR, Deeth HC (2013) Characteristics of a calcium-milk coagulum. J Food Eng 114:147-152

Ramasubramanian L, D'Arcy BR, Deeth HC, Eustina OH (2014) The rheological properties of calciuminduced milk gels. J Food Eng 130:45-51

Roefs SPFM, de Groot-Mostert AEA, van Vliet T (1990) Structure of acid casein gels. 1. Formation and model of gel network. Colloids Surf 50:141-159

Simons JFA, Kosters HA, Visschers RW, de Jongh HHJ (2002) Role of calcium as trigger in thermal $\beta$ lactoglobulin aggregation. Arch Biochem Biophys 406:143-152 
Singh H (2004) Heat stability of milk. Int J Dairy Technol 57:111-119

Singh H, Roberts MS, Munro PA, Teo CT (1996) Acid-induced dissociation of casein micelles in milk: effects of heat treatment. J Dairy Sci 79:1340-1346

Tran Le T, El-Bakry M, Neirynck N, Bogus M, Hoa HD, van der Meeren P (2007) Hydrophilic lecithins protect milk proteins against heat-induced aggregation. Colloid Surfaces B 60:167-173

Udabage P, McKinnon IR, Augustin MA (2000) Mineral and casein equilibria in milk: effects of added salts and calcium-chelating agents. J Dairy Res 67:361-370

van Hooydonk ACM, Hagedoorn HG, Boerrigter IJ (1986) pH-induced physicochemical changes of casein micelles in milk and their effect on renneting. 1. Effect of acidification on physicochemical properties. Neth Milk Dairy J 40:281-296

Vasbinder AJ, de Kruif CG (2003) Casein-whey protein interactions in heated milk: the influence of pH. Int Dairy J 13:669-677

Visser J, Minihan A, Smits P, Tjan SB, Heertje I (1986) Effects of $\mathrm{pH}$ and temperature on the milk salt system. Neth Milk Dairy J 40:351-368

Walstra P, Jenness R (1984) Dairy chemistry and physics. Wiley: New York, USA; pp 1-11, $42-57$ and 98-122

Zoon P, van Vliet T, Walstra P (1989) Rheological properties of rennet-induced skim milk gels. 4. The effect of $\mathrm{pH}$ and $\mathrm{NaCl}$. Neth Milk Dairy J 43:17-34 